\title{
The Antimalarial Properties Of Essential Oils Of The Leaves Of Malaysian Plectranthus Amboinicus (Lour) Spreng In Mice Infected With Plasmodium Berghei
}

\author{
Norazsida,.$^{a}$, Pakeer, O. $^{b}$, Taher, $M .^{c}$ \\ ${ }^{a}$ Department of Biomedical Sciences, Kulliyyah of Allied Health Sciences, \\ ${ }^{b}$ Department of Basic Medical Sciences, Kulliyyah of Medicine, \\ 'Department of Pharmaceutical Technology, Kulliyyah of Pharmacy, International Islamic University \\ Malaysia
}

\begin{abstract}
This study was conducted to evaluate the phytochemical contents and antimalarial properties of the oils extracted from the leaves of Malaysian Plectranthus amboinicus in mice infected with Plasmodium berghei. The essential oils were extracted and prepared by using steam distillation technique and subjected to phytochemical screening by using GC-MS. Antimalarial activity of different extract doses of the essential oil was tested in vivo in ICR mice infected with Plasmodium berghei (PZZ1/100) during early, established and residual infections. In all, 5 compounds made up $88.34 \%$ of total oil and the major chemical compounds were carvacrol $(85.14 \%)$, thymoquinone (1.65\%), terpinen-4-ol $(0.70 \%)$, octenol $(0.62 \%)$ and thymol $(0.23 \%)$. Antimalarial assay showed this essential oil as a potential prophylactic agent with the percentage chemosuppression of $45.23 \%, 18.28 \%, 45.38 \%$ and $58.26 \%$ while treated with $50,200,400$ and $1000 \mu \mathrm{L} / \mathrm{kg}$ respectively of essential oil and curative agent with percentage of chemo suppression of $54.10 \%, 47.35 \%$, $56.75 \%$ and $65.38 \%$ while treated with the above dose of essential oil. Statistically no reduction of parasitemia was calculated for suppressive test. The extract has prophylactic and curative effects on P.berghei in mice.
\end{abstract}

Keywords: phytochemical, toxicity, Plectranthus amboinicus, antimalarial.

\section{Introduction}

Malaria is a vector borne disease prevalent in many tropical countries and is caused by five Plasmodium species transmitted by female Anopheles mosquitoes. In Malaysia the prevalence remains high i.e. in 2014, 1779 cases (the highest record) was reported in Sabah, followed by Sarawak with 1301 cases and 843 cases in Peninsular Malaysia. ${ }^{1}$ The discovery of Plasmodium knowlesi in human previously thought to be a zoonosis, has also complicated the picture of malaria in Malaysia. The occurrence of knowlesi malaria in Sarawak, Sabah, and Pahang is higher than other states. ${ }^{2}$

Malaria continues to kill many residents in the tropics, especially children despite the availability of many drugs to treat the disease and the use of

Corresponding author:

Norazsida Ramli,

Department of Biomedical Sciences,

Kulliyyah of Allied Health Sciences,

International Islamic University Malaysia,

Jalan Sultan Ahmad Shah,

25200 Kuantan, Pahang.

Email: norazsida@iium.edu.my,

Telephone no: +609-5716400 (ext:3429),

Fax no: $+609-5716776$ insecticide impregnated bednets. $\stackrel{2}{-}$ The occurrence of resistance to many of the drugs is a major concern. Thus, the search for new antimalarials is continuing, particularly the evaluation of available traditional medicine from many communities.

Plectranthus amboinicus is an aromatic plant that is found growing throughout Malaysia and in several Asian and South American countries. The plant is claimed by traditional medicinal practitioners ${ }^{6,7}$ to have antimicrobial ${ }^{3}$, antifungal ${ }^{4}$, antimalarial ${ }^{5}$ and fever soothing properties. Study on the ethanolic extract of Malaysian P. amboinicus against malariainfected mice proved it as a promising prophylaxis agent. $^{8}$ On the other hand, it has been shown that the aqueous extract of the leaves of the Indian $P$. amboinicus is able to reduce the parasitemia of Plasmodium berghei yoelli in suppression test in mice and this supports the potential use of these leaves as a medicinal plant to treat malaria fever in India. 5

Thus far there is no documented study on the essential oil of the Malaysian $P$. amboinicus. This study aims to determine the chemical composition of the essential oil, and explore the potential use of the essential oil as antimalarial against $P$. berghei in vivo. 


\section{Methodology}

\section{Plant Material}

Leaves of $P$. amboinicus were collected in May 2011 from an orchard in Kuantan, Pahang, Malaysia and was confirmed by a taxonomist from Forest Research Institute Malaysia (FRIM). The plant specimen (MT11-13) was deposited in the herbarium of Kulliyyah of Pharmacy, International Islamic University Malaysia (IIUM) as a reference point.

\section{Extraction}

Essential oils from the ground samples were extracted using steam distillation technique. ${ }^{9} P$. amboinicus leaves were ground into small pieces by a food processor and weighed $(941 \mathrm{~g})$ and transferred to a distiller. The extracted essential oil was stored at $4^{\circ} \mathrm{C}$ until further use. ${ }^{10}$

\section{Phytochemical screening}

Phytochemical screening of the essential oil was conducted using Gas Chromatography Mass Spectrometry (GC-MS). ${ }^{11}$ GC-mass spectroscopy (GC-MS) analysis of the extracted essential oils was performed using Varian 3800 gas chromatography equipped with Varian $1200 \mathrm{~L}$ single quadrupole mass spectrometer. GC conditions were the same as stated for GC analysis and the same column was used.

The mass spectrometer was operated in the electron impact mode at $70 \mathrm{eV}$. Ion source and transfer line temperature was kept at $250^{\circ} \mathrm{C}$. The mass spectra were obtained by centroid scan of the mass range from 40 to $1,000 \mathrm{amu}$. The compounds were identified based on the comparison of their retention indices (RI), retention time (RT) and mass spectra of WILEY, NIST library data of the GC-MS system and literature data ${ }^{12}$.

\section{Animals}

Female ICR mice (mean weight \pm S.D; $21.65 \pm 3.32$ g) and males $(25.08 \pm 3.46 \mathrm{~g})$ were obtained from the Animal Centre of Universiti Kebangsaan Malaysia (UKM) and housed under standard conditions $\left(22^{\circ} \mathrm{C}\right.$ with 12 hrs dark and 12 hrs light) and were maintained on a standard pellet feed and water ad libitum. Permission and approval for animal studies were obtained from the Animal Ethics Committee, International Islamic University Malaysia (IIUM). During the acclimatization period of 7 days the animals were observed daily for general health condition.

\section{Parasite inoculation}

A chloroquine sensitive strain of Plasmodium berghei (PZZ1/100) was obtained from the Parasitology laboratory, School of Bioscience and Biotechnology, UKM and was maintained by sub- passage in ICR mice. The desired blood volume was drawn from the donor mouse by cardiac puncture and diluted serially in Alsever's solution. The final suspension contained approximately $1 \times 10^{6}$ infected RBC's in every $0.1 \mathrm{~mL}$ suspension. This $0.1 \mathrm{~mL}$ suspension was injected into mice intraperitoneally to initiate infections (modification from). ${ }^{13}$ The infected mice were then randomized into five mice/cage and maintained in the Animal Retention Room, Kulliyyah of Allied Health Sciences, IIUM, in accordance with the internationally accepted guidelines for laboratory animal use and care.

\section{In vivo erythrocytic antimalarial assay}

A series of experiments with ethanolic leaves extract was done using $50,200,400$ and $1000 \mu \mathrm{L} / \mathrm{kg}$ doses compared to control groups treated with distilled water (containing 10\% DMSO, the solvent of the test extracts). The reference groups were treated with 2 standard drugs (chloroquine 20 $\mathrm{mg} / \mathrm{kg} /$ day or Fansidar $12 \mathrm{mg} / \mathrm{kg} /$ day).

Malaria infection in experimental animals was established in female ICR mice by the intraperitoneal (i.p.) administration of donor female ICR mouse blood containing about $1 \times 10^{6}$ parasites. Three different treating experimental groups of malaria infections were setup, i.e., 4-Day suppressive, curative and prophylactic methods according to earlier research ${ }^{14} 1516$.

In the suppressive experiment, the mice were treated orally 2-4 hours post-infection (D0). This treatment was repeated for the next three days (D1 to D3). On the fifth day (D4), blood smears were prepared from each mouse and stained with Giemsa's stain. The mean survival time (in days) for each group was determined over a period of 30 days post-infection.

In the curative experiment however, the mice were treated 72 hours post-infection (D0) and treatments were continued daily for a week (D7). The mean survival time (in days) for each group was determined over a period of 30 days post-infection.

In the prophylactic experiment, the mice were administered with the treatment before infection, which was given for 3 consecutive days (D0-D2). On the fourth day (D3), all mice were infected with $1 \times 10^{6} \mathrm{P}$. berghei and kept for the next 3 days. On the seventh day, blood smears were prepared from the tail blood of each mouse. The films were then stained with Giemsa's stain to determine parasitized erythrocytes. The percentage of parasitaemia was determined by counting the parasitized red blood cells out of 9,000 in random fields of the microscope:

$\%$ Parasitaemia $=[$ No. of parasitized RBC/Total no. of RBC counted] $\times 100$ 
Average percentage chemosuppression was calculated as: $100 \times[A-B / A]$ where, $A$ is the mean percentage parasitaemia in the negative control group and $B$ is the mean percentage parasitaemia in the test group. The mice were weighed every two days and the status was observed daily until day 30 survival.

\section{Statistical analysis}

Values are expressed as mean \pm Standard deviation (S.D). Results were analyzed statistically using OneWay ANOVA and Kaplan-Meier Survival Analysis. The significant difference between control and treated groups were considered at $p<0.05$ level. ${ }^{17}$

\section{Results}

\section{Phytochemical screening}

The leaves of $P$. amboinicus yielded $0.19 \%(\mathrm{v} / \mathrm{w})$ of essential oils and was dark yellow in colour. Table 1 shows the chemical composition of the essential oils analysed by GC-MS. Five compounds were identified accounting for $88.34 \%$ of total oil and the major chemical compounds were mainly carvacrol $(85.14 \%)$, thymoquinone $(1.65 \%)$, terpinen4 -ol $(0.70 \%)$, octenol $(0.62 \%)$ and thymol.

Table I: Chemical composition of the essential oil from the fresh leaves of Plectranthus ambonicus

\begin{tabular}{llll}
\hline $\begin{array}{l}\text { Peak } \\
\text { no. }\end{array}$ & RT & Chemical compound & $\begin{array}{l}\text { Percentage } \\
(\%)\end{array}$ \\
\hline 1 & 7.37 & Octenol & 0.62 \\
2 & 14.04 & Terpinen-4-ol & 0.70 \\
3 & 16.43 & Thymoquinone & 1.65 \\
4 & 17.95 & Thymol & 0.23 \\
5 & 18.21 & Carvacrol & 85.14 \\
\hline Total & & & 88.34 \\
\hline
\end{tabular}

$\mathrm{RT}=$ Retention time

\section{Antimalarial assay}

\section{Parasitaemia and Chemo-suppression}

Prophylactic experiment showed the potential of $P$. amboinicus essential oils as a prophylactic agent. Table 2 shows the percentage chemosuppression of $45.23 \%, 18.28 \%, 45.38 \%$ and $58.26 \%$ while treated with $50,200,400$ and $1000 \mu \mathrm{L} / \mathrm{kg}$ respectively of essential oil. Also this oil also showed evidence of being a potential curative agent for malaria even though the percentage chemo suppression values were not comparable to chloroquine.

The essential oil percentage of chemo suppression for curative test were $54.10 \%, 47.35 \%, 56.75 \%$ and
$65.38 \%$ while treated with $50,200,400$ and $1000 \mu \mathrm{L} /$ $\mathrm{kg}$ of essential oil respectively. However, this oil showed no significant suppressive properties in mice infected with P.berghei.

\section{Antimalarial assay}

\section{Parasitaemia and Chemo-suppression}

Prophylactic experiment showed the potential of $P$. amboinicus essential oils as a prophylactic agent. Table 2 shows the percentage chemosuppression of $45.23 \%, 18.28 \%, 45.38 \%$ and $58.26 \%$ while treated with $50,200,400$ and $1000 \mu \mathrm{L} / \mathrm{kg}$ respectively of essential oil. Also this oil also showed evidence of being a potential curative agent for malaria even though the percentage chemo suppression values were not comparable to chloroquine.

The essential oil percentage of chemo suppression for curative test were $54.10 \%, 47.35 \%, 56.75 \%$ and $65.38 \%$ while treated with $50,200,400$ and $1000 \mu \mathrm{L} /$ $\mathrm{kg}$ of essential oil respectively. However, this oil showed no significant suppressive properties in mice infected with P.berghei.

\section{Body Weight}

In prophylactic experiment all treatment group mice gained body weight even though after 4 days of infection. Only control group showed reduced body weight post infection. Curative experiment showed that all treatment groups gained body weight on day 2 post infections but it showed reduction in body weight during the following days till the 30 days of observation.

On the other hand, all treatment group mice for suppressive experiment (except the Chloroquine group) and control reduced in body weight post infection. For both curative and suppressive experiment, only Chloroquine group gained body weight throughout the 30 days of observation.

\section{Survival Analysis}

Survival analysis of the treatment mice that were in the suppressive and curative experiments (Figures 1 \& 2) showed that only chloroquine group mice survived till the end of study. All experimental mice (treated with essential oil) died one by one over the experimental period of 30 days. 
Table II: Erythrocytic-antiplasmodial assay of the essential oil of Plectranthus amboinicus during early, established and residual $P$. berghei infection

\begin{tabular}{|c|c|c|c|c|c|}
\hline Test & Drug/extract & Dose $(\mu \mathrm{L} / \mathrm{kg})$ & $\begin{array}{l}\text { \%Parasitaemia } \\
(\text { mean } \pm \text { S.D) }\end{array}$ & $\begin{array}{l}\text { \%chemo- } \\
\text { suppresion }\end{array}$ & Significance \\
\hline $\begin{array}{c}\text { Prophylactic } \\
\text { test }\end{array}$ & $\begin{array}{c}\text { Control } \\
\text { T1 } \\
\text { T2 } \\
\text { T3 } \\
\text { T4 } \\
\text { Fansidar }\end{array}$ & $\begin{array}{c}0.2 \mathrm{~mL} \\
50 \\
200 \\
400 \\
1000 \\
12 \mathrm{mg} / \mathrm{kg}\end{array}$ & $\begin{array}{c}13.73 \pm 0.96 \\
7.52 \pm 1.01 \\
11.22 \pm 0.50 \\
7.50 \pm 0.35 \\
5.73 \pm 0.24 \\
0\end{array}$ & $\begin{array}{c}45.23 \\
18.28 \\
45.38 \\
58.27 \\
100\end{array}$ & $\begin{array}{l}0.000^{* * *} \\
0.000^{* * *} \\
0.000^{* * *} \\
0.000^{* * *} \\
0.000^{* * *}\end{array}$ \\
\hline $\begin{array}{l}\text { Suppressive } \\
\text { test }\end{array}$ & $\begin{array}{c}\text { Control } \\
\text { T1 } \\
\text { T2 } \\
\text { T3 } \\
\text { T4 } \\
\text { Chloroquine }\end{array}$ & $\begin{array}{c}0.2 \mathrm{~mL} \\
50 \\
200 \\
400 \\
1000 \\
20\end{array}$ & $\begin{array}{c}11.44 \pm 1.29 \\
10.11 \pm 1.01 \\
10.72 \pm 0.81 \\
11.82 \pm 1.68 \\
12.54 \pm 0.54 \\
0\end{array}$ & $\begin{array}{c}11.63 \\
6.30 \\
\mathrm{Nil} \\
\mathrm{Nil} \\
100\end{array}$ & $\begin{array}{c}0.259 \\
0.791 \\
0.976 \\
0.472 \\
0.000^{* * *}\end{array}$ \\
\hline Curative test & $\begin{array}{c}\text { Control } \\
\text { T1 } \\
\text { T2 } \\
\text { T3 } \\
\text { T4 } \\
\text { Chloroquine }\end{array}$ & $\begin{array}{c}0.2 \mathrm{~mL} \\
50 \\
200 \\
400 \\
1000 \\
20\end{array}$ & $\begin{array}{c}11.70 \pm 0.33 \\
5.37 \pm 0.34 \\
6.16 \pm 0.38 \\
5.06 \pm 0.52 \\
4.05 \pm 0.43 \\
0\end{array}$ & $\begin{array}{c}54.10 \\
47.35 \\
56.75 \\
65.38 \\
100\end{array}$ & $\begin{array}{l}0.000^{* * *} \\
0.000^{* * *} \\
0.000^{* * *} \\
0.000^{* * *} \\
0.000^{* * *}\end{array}$ \\
\hline
\end{tabular}

${ }^{*} p<0.05$ as compared with control

${ }^{* *} p<0.01$ as compared with control

${ }^{* * *} p<0.001$ as compared with control

$\mathrm{n}=5$ for each group of treatments

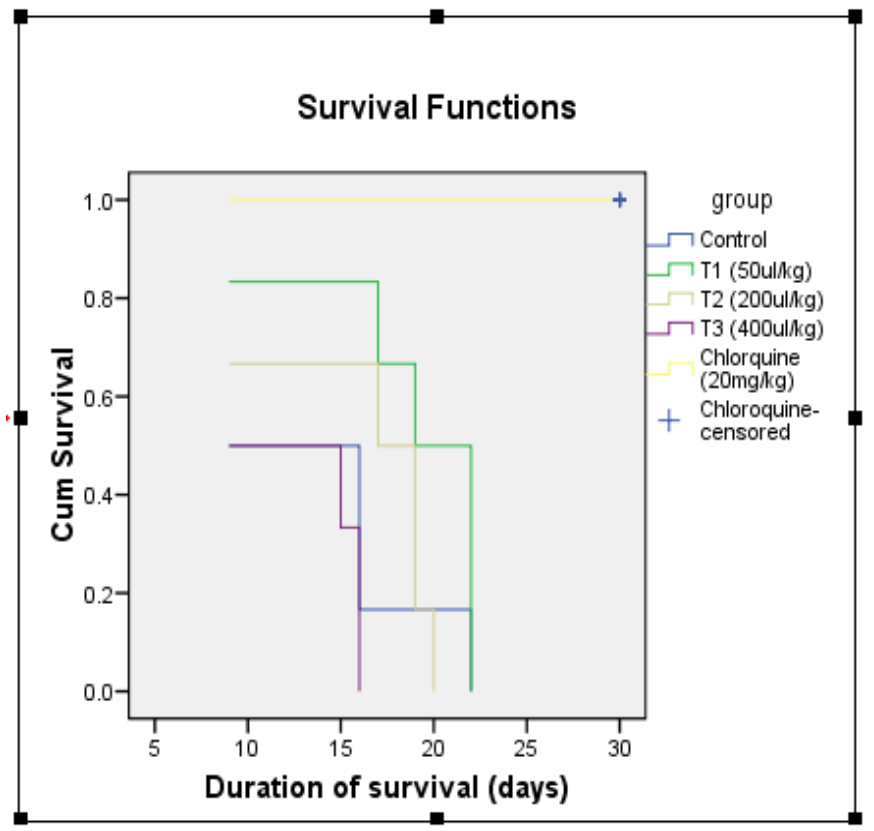

Figure 1 Graph of Kaplan-Meier survival function of different groups of treatment throughout 30 days of curative test

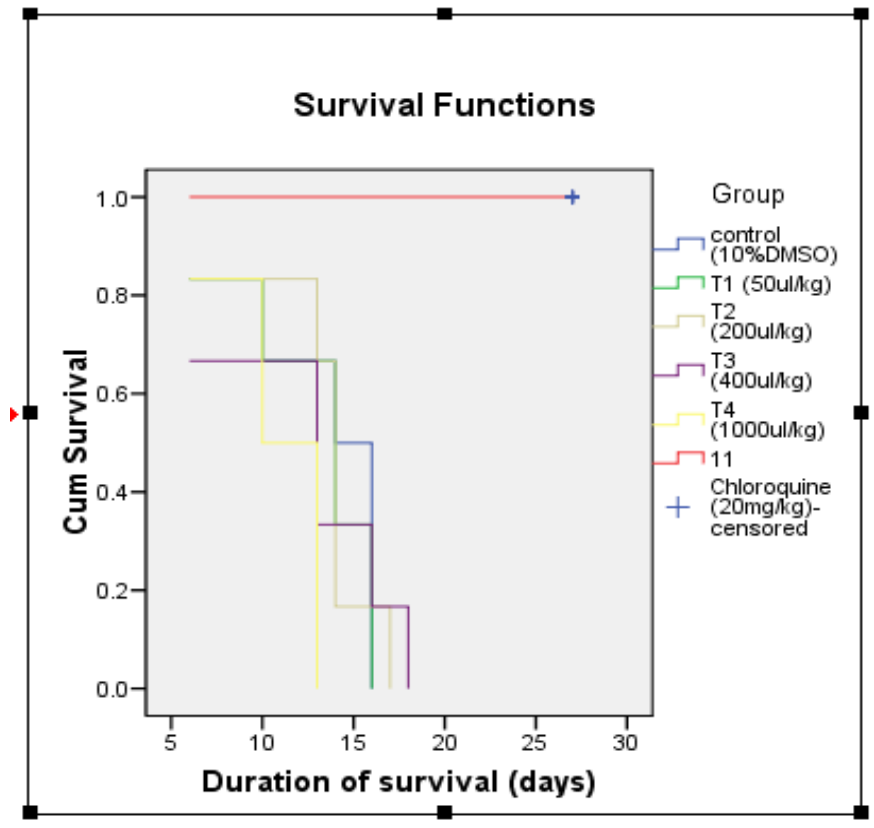

Figure 2 Graph of Kaplan-Meier survival function of different groups of treatment throughout 30 days of suppressive test 


\section{DISCUSSIONS}

In this study, phytochemical screening of the essential oils of $P$. amboinicus showed the presence of carvacrol in very high amounts (85.14\%). This is an expected finding as carvarol is reported as a major constituent in $P$. amboinicus from around the world. 6,18-21 Malaysian plant isolate is shown to have higher amounts of carvacrol compared with the Indian $P$. amboinicus leaves (collected from Cuddalore district, Tamil Nadu, India) flower and aerial part (collected from the medicinal garden of Regional Medical Research Centre (RMRC), Belgaum, Karnataka, India) which contain only $28.65 \%, 50.98$ $\%$ and $77.16 \%$ of carvacrol respectively. ${ }^{11,22}$ The Indian isolates of $P$. amboinicus leaves collected from Western Ghats of Siruvani hills of Coimbatore, India also showed lower content of carvacrol (14\%). 23

Phytochemical, nutrition content and pharmacological activities of this plant have been studied extensively by Indian researchers as the plant is considered as an integral part of medicinal herb garden. ${ }^{24,25}$ The essential oil extracted from the Indian plant was proven scientifically to have antimicrobial, bactericidal, fungicidal, larvicidal and insecticidal activities. 4, 11, 19, 21, 23, 26-29

Carvacrol itself has earlier been proven to have many medicinal properties. It has been proven to act as hepatoprotective agent against thioacetamide (TAA). ${ }^{30}$ It is also shown to have potential antigenotoxic agent ${ }^{31}$ and antimicrobial properties. 32,33 The antibacterial activity of carvacrol is attributed to its considerable effect on the structural and functional properties of cytoplasmatic membrane. ${ }^{32}$ Also, the higher level of thymoquinone $(1.65 \%)$ in the essential oils of the Malaysian isolate $P$. amboinicus increases the value of this plant, as thymoquinone has antitumor properties. The compound has been shown to protect against damage of the heart, liver and kidney in animal studies. $^{34,35}$ The presence of thymoquinone in Lamiaceae family also has been reported in Origanum vulgare L. spp. hirtum. ${ }^{36}$

The essential oils of leaves of $P$. amboinicus has potential to be used as a prophylactic agent and surprisingly, it also has potential to be used as a curative agent of rodent malaria even though the percentage of chemo-suppression values is still considered lower compared to chloroquine. No reduction of parasitemia was observed during the experiment of the suppressive experiment.

With the decline in the percentage parasitemia and percentage chemo-suppression, prophylaxis experiment of $P$. amboinicus against $P$. berghei also showed the increase of body weight post 4 days of infection suggesting the positive effect of this essential oil as a prophylactic agent. In contrast, even though the reduction of parasitemia had been observed in curability experiment, none of the treated mice showed increase in body weight till the end of the study. This may be due to the insufficient treatment with extract to reduce parasitaemia. It is possible that increasing the period of treatment may bring about the reduction of parasitemia, the return of normal body weight and extend the survival rate.

Thus far, there is no documented study on the antimalarial properties of the essential oils of the Malaysian $P$. amboinicus and this study shows that this plant possesses a very promising potential prophylactic agent of $P$. berghei in mice. Thus, there is a potential prophylactic and curative agent for rodent malaria.

\section{ACKNOWLEDGMENTS}

This work was supported by International Islamic University Malaysia under IIUM Endowment B Grant Scheme (EDB13-067-0952).

\section{REFERENCES}

1. Malaysia DoS. Compendium of Environment Statistics Malaysia 2015. 2015:146.

2. Singh B and Daneshvar C. Plasmodium knowlesi malaria in Malaysia. Med J Malaysia, 2010; 65:166-72.

3. Devi NN, Shankar PD, Femina $W$, and Paramasivam T. Antimicrobial efficacy of green synthesized silver nanoparticles from the medicinal plant Plectranthus amboinicus. International Journal of Pharmaceutical Sciences Review and Research, 2012; 12:164-8.

4. Murthy PS, Ramalakshmi K, and Srinivas P. Fungitoxic activity of Indian borage (Plectranthus amboinicus) volatiles. Food Chemistry, 2009; 114:1014-8.

5. Periyanayagam K, Nirmala DK, Suseela L, Uma $A$, and Ismail $M$. In vivo antimalarial activity of leaves of Plectranthus amboinicus (lour) spreng on Plasmodium berghei yoelii. The Journal of communicable diseases, 2008; 40:121-5.

6. Gurib-Fakim A, Sewraj MD, Narod F, and Menut C. Aromatic Plants of Mauritius: Volatile Constituents of the Essential Oils of Coleus aromaticus Benth., Triphasia trifolia (Burm. f.) and Eucalyptus kirtoniana F. Muell. Journal of Essential Oil Research, 1995; 7:215-8.

7. Jain $S$ and Lata $S$. Unique indigenous Amazonian uses of some plants growing in India. Indig Knowl Devel Monit, 1996; 4:21-3.

8. Ramli N, Ahamed POS, Elhady HM, and Taher M. Antimalarial activity of Malaysian Plectranthus amboinicus against Plasmodium berghei. Pharmacognosy research, 2014; 6:280.

9. Gundidza M, Gweru N, Magwa M, Mmbengwa V, and Samie A. The chemical composition and biological activities of essential oil from the fresh leaves of Schinus terebinthifolius from Zimbabwe. African Journal of Biotechnology, 2009; 8 . 
10. Gweru N, Gundidza M, Magwa M, Ramalivhana $\mathrm{N}$, Humphrey G, Samie A and Mmbengwa V. Phytochemical composition and biological activities of essential oil of Rhynchosia minima (L)(DC)(Fabaceae). African Journal of Biotechnology, 2009; 8.

11. Senthilkumar A and Venkatesalu V. Chemical composition and larvicidal activity of the essential oil of Plectranthus amboinicus (Lour.) Spreng against Anopheles stephensi: a malarial vector mosquito. Parasitology research, 2010; 107:1275-8.

12. Lahlou M. Methods to study the phytochemistry and bioactivity of essential oils. Phytotherapy Research, 2004; 18:435-48.

13. Al-Adhroey AH, Nor ZM, Al-Mekhlafi HM, Amran $\mathrm{AA}$, and Mahmud R. Evaluation of the use of Cocos nucifera as antimalarial remedy in Malaysian folk medicine. Journal of Ethnopharmacology, 2011; 134:988-91.

14. Peters $W$ and Robinson $B$. The chemotherapy of rodent malaria. XLVII. Studies on pyronaridine and other Mannich base antimalarials. Annals of tropical medicine and parasitology, 1992; 86:455-65.

15. Saidu K, Onah J, Orisadipe A, Olusola A, Wambebe C, Gamaniel K. Antiplasmodial, analgesic, and anti-inflammatory activities of the aqueous extract of the stem bark of $<i>$ Erythrina senegalensis $</ i>$. Journal of Ethnopharmacology, 2000; 71:275-80.

16. Schetters T, BREDA JVRV, Hermsen C, Curfs J, and Eling $W$. Protective and pathological activity in serum of mice developing resistance to Plasmodium berghei infection. Parasite immunology, 1989; 11:413-23.

17. SPSS S. version 17. SPSS Inc, Chicago, USA, 2009.

18. Pino J, Rosado A, and Borges P. Volatile components in the essential oil of wild oregano (Coleus amboinicus Lour.). Food/Nahrung, 1990; 34:819-23.

19. Prudent D, Perineau F, Bessiere J, Michel G, and Baccou J. Analysis of the Essential Oil of Wild Oregano from Martinique (Coleus aromaticus Benth.)-Evaluation of Its Bacteriostatic and Fungistatic Properties. Journal of Essential Oil Research, 1995; 7:16573.

20. Patel R, Mahobia NK, Gendle R, Kaushik B, and Singh SK. Diuretic activity of leaves of Plectranthus amboinicus (Lour) Spreng in male albino rats. Pharmacognosy research, 2010; 2:86.

21. Marwah R, Fatope M, Deadman M, Ochei J, and Al-Saidi S. Antimicrobial activity and the major components of the essential oil of Plectranthus cylindraceus. Journal of applied microbiology, 2007; 103:1220-6.

22. Joshi RK, Badakar V, and Kholkute SD. Carvacrol Rich Essential Oils of Coleus aromaticus (Benth.) from Western Ghats Region of North West Karnataka, India. Advances in Environmental Biology, 2011; 5.
23. Manjamalai A, Alexander $\mathrm{T}$, and Grace VM. BIOACTIVE EVALUATION OF THE ESSENTIAL OIL OF PLECTRANTHUS AMBOINICUS BY GC-MS ANALYSIS AND ITS ROLE AS A DRUG FOR MICROBIAL INFECTIONS AND INFLAMMATION. International Journal of Pharmacy \& Pharmaceutical Sciences, 2012; 4.

24. Mallavarapu GR, Rao L, and Ramesh S. Essential oil of Coleus aromaticus Benth. from India. Journal of Essential Oil Research, 1999; 11:7424.

25. Khare RS, Banerjee $S$, and Kundu K. COLEUS AROMATICUS BENTH--A NUTRITIVE MEDICINAL PLANT OF POTENTIAL THERAPEUTIC VALUE. International Journal of Pharma \& Bio Sciences, 2011; 2 .

26. Samuel C, Srivastava L, and Tripathi S. Protection of dry-fruits from fungal infestation by essential oil of Coleus amboinicus. Indian Journal of Plant Protection, 1995; 23:174-9.

27. Singh G, Singh OP, Prasad $Y$, De Lampasona $M$, and Catalan C. Studies on essential oils, Part 33: chemical and insecticidal investigations on leaf oil of Coleus amboinicus Lour. Flavour and fragrance journal, 2002; 17:440-2.

28. Oliveira RdAGd, Lima EdO, Souza ELd, et al. Interference of Plectranthus amboinicus (Lour.) Spreng essential oil on the anti-Candida activity of some clinically used antifungals. Revista Brasileira de Farmacognosia, 2007; 17:186-90.

29. da Costa JGM, Pereira CKB, Rodrigues FFG, and de Lima SG. Chemical Composition, Antibacterial and Fungicidal Activities of Leaf Oil of Plectranthus amboinicus (Lour.) Spreng. Journal of Essential Oil Research, 2010; 22:1835.

30. Nafees S, Ahmad S, Arjumand W, et al. Carvacrol ameliorates thioacetamide-induced hepatotoxicity by abrogation of oxidative stress, inflammation, and apoptosis in liver of Wistar rats. Human \& experimental toxicology, 2013; 32:1292-304.

31. İpek E, Tüylü BA, and Zeytinoğlu H. Effects of carvacrol on sister chromatid exchanges in human lymphocyte cultures. Cytotechnology, 2003; 43:145-8.

32. Nostro A and Papalia T. Antimicrobial activity of carvacrol: current progress and future prospectives. Recent patents on anti-infective drug discovery, 2012; 7:28-35.

33. Nostro A, Roccaro AS, Bisignano G, Marino A, Cannatelli MA, Pizzimenti FC, Cioni PL, Procopio F, Blanco AR. Effects of oregano, carvacrol and thymol on Staphylococcus aureus and Staphylococcus epidermidis biofilms. Journal of medical microbiology, 2007; 56:51923.

34. Badary OA, Al-Shabanah OA, Nagi MN, Al-Bekairi AM, and Elmazar M. Acute and subchronic toxicity of thymoquinone in mice. Drug Development Research, 1998; 44:56-61. 
35. Nagi MN and Mansour MA. Protective effect of thymoquinone against doxorubicin-induced cardiotoxicity in rats: a possible mechanism of protection. Pharmacological research, 2000; 41:283-9.

36. Milos M, Mastelic J, and Jerkovic I. Chemical composition and antioxidant effect of glycosidically bound volatile compounds from oregano (Origanum vulgare L. ssp. hirtum). Food Chemistry, 2000; 71:79-83. 
